\begin{tabular}{|c|c|c|}
\hline 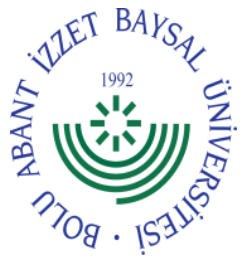 & $\begin{array}{l}\text { International Journal of Agriculture and Wildlife } \\
\qquad \text { Science } \\
\text { http://dergipark.org.tr/jaws }\end{array}$ & 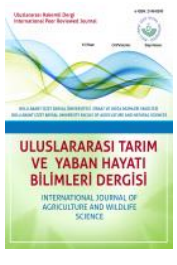 \\
\hline
\end{tabular}

Research Article

Mitigation of Salinity Stress on Chickpea Germination by Salicylic Acid Priming

Mustafa Ceritoğlu*, Murat Erman

Department of Field Crops, Faculty of Agriculture, Siirt University, Siirt, Turkey

Received: 28.07.2020 Accepted: 25.09.2020

\section{Keywords:}

Hydro-priming, osmopriming, ion toxicity, stress alleviation, uniformity of germination

*Corresponding author ceritoglu@siirt.edu.tr

Abstract. Salinity is a global problem that threatens chickpea (Cicer arietinum L.) cultivation in all stages from germination to maturity. Also, salt-affected areas in the World are increasing by the day. Germination is one of the primary stages affecting plant growth and seed yield. Thus, germination performance of seeds has a vital role in vegetative and productive stages. Seed priming, a cheap and easily applicable technique, improves the germination performance by regulating enzymatic reactions and controlling water intake. Seed priming is controlled hydration of seeds soaked in a solution that has low osmotic potential to start the germination metabolism without elongation of radical. The aim of the study was to investigate the effects of different priming treatments on germination traits of chickpea under saline conditions. Three levels of salinity (control, $50 \mathrm{mM}$ and $100 \mathrm{mM} \mathrm{NaCl}$ ) and 5 priming treatments (nonprimed, hydro-priming, $0.1 \mathrm{mM}, 0.2 \mathrm{mM}$ and $0.3 \mathrm{mM}$ salicylic acid) were used in the study. Germination percentage (GP), mean germination time (MGT), germination rate (GR), germination index (GI) and coefficient of uniformity of germination (CUG) were varied between $80.7-98.3 \%, 1.40-2.67$ day, 38.1-75.7, 37.5-72.5 and 0.3-0.7, respectively. Although all treatments caused significant positive effects, the $0.2 \mathrm{mM}$ SA mostly improved the germination traits in the study. Also, it was determined that $0.2 \mathrm{mM}$ salicylic acid priming is the threshold for chickpea and higher concentrations have inhibitory effects on the germination process.
\end{abstract}

\title{
Nohut Çimlenmesi Üzerine Tuzluluk Stresinin Salisilik Asit Priming ile Azaltılması
}

\section{Anahtar kelimeler:}

Hidro-priming, osmopriming, iyon toksisitesi, stress azaltma, çimlenme üniformitesi
Özet. Tuzluluk, nohut (Cicer arietinum L.) tarımını çimlenmeden olgunluğa kadar her aşamada tehdit eden küresel bir sorundur. Ayrıca, yeryüzünde tuzluluktan etkilenen alanlar giderek artmaktadır. Çimlenme ürün kalitesini ve tane verimini etkileyen evrelerin başında gelir. Bu nedenle, tohumların çimlenme performansları vejetatif ve generatif gelişim dönemleri açısından hayati önem taşımaktadır. Ucuz ve kolay uygulanabilir bir teknik olan priming, su alımını kontrol ederek ve enzimatik reaksiyonları düzenleyerek çimlenme performansının artmasını sağlar. Priming, düşük osmotik potansiyele sahip bir çözeltide bekletilerek tohumun çimlenme metabolizmasının kökcük çıkışı olmaksızın başlatıldığı kontrollü su alımını ifade eder. Çalışmanın amacı, tuzluluk stresi altındaki nohutta farklı priming uygulamalarının çimlenme özellikleri üzerine etkilerini belirlemektir. Çalışmada 3 tuzluluk seviyesi (kontrol, $50 \mathrm{mM} \mathrm{NaCl}$ ve $100 \mathrm{mM}$ $\mathrm{NaCl}$ ) ve 5 ekim öncesi uygulama (kontrol, hidro-priming, $0.1,0.2$ ve $0.3 \mathrm{mM}$ salisilik asit) kullanılmıştır. Çimlenme yüzdesi (\% 80.7-98.3), ortalama çimlenme süresi (1.40-2.67 gün), çimlenme hızı (38.1-75.7), çimlenme indeksi (37.5-72.5) ve çimlenme üniformluk katsayısı (0.3-0.7) değerleri , , ve Belirlenmiştir. Çalışmadaki tüm uygulamalar önemli pozitif etkilere sebep olmasına rağmen $0.2 \mathrm{mM}$ SA uygulması çimlenme özelliklerini en çok iyileştiren uygulama olmuştur. Ayrıca, $0.2 \mathrm{mM} \mathrm{SA}$ uygulamasının nohutta eşik değer olduğu, daha yüksek konsantrasyonların çimlenme süreci üzerine engelleyici/azaltııı etki gösterdiği tespit edilmiştir. 


\section{INTRODUCTION}

Chickpea (Cicer arietinum L.) is one of the most nutritionally and economically important grain legumes. Nearly 17.2 million tons of chickpea is grown on 17.1 million hectares area over the World (FAOSTAT, 2018). Due to its highly nutritious composition which includes carbohydrate (54-71\%), protein (13-31\%), vitamins, phosphorus and physiologically active ingredients, chickpea constitutes a substantial step of essential nutrients in many regions (Xing et al., 2020). Also, chickpea, similar to other grain legumes, is an important part of rotation systems (Francis et al., 1986; Ceritoglu and Erman, 2019) due to its high adaptability (Gan et al., 2009; Soysal et al., 2020) and nitrogen fixation that enhances $\mathrm{N}$ content and productivity of soil (Soe et al., 2020).

Some abiotic and biotic stresses reduced chickpea productivity up to 1 ton ha ${ }^{-1}$ although it has the potential to achieve 3.5-4 ton ha ${ }^{-1}$ under optimum growth conditions (Roorkiwal et al., 2018). Drought stress might restrict chickpea yield by nearly 33\% (Hajjarpoor et al., 2018) heat and drought stresses together cause a reduction of up to $70 \%$ (Varshney et al., 2014). The other vital stress, salinity, also threatens chickpea cultivation. According to estimates, the 7 billion hectares (Bha) land is arable on the world, of which 1.5 Bha can be cultivated, 340 million hectares (Mha) is saline and, $560 \mathrm{Mha}$ is sodic (Shahid et al., 2018). Due to irrigation practices, salt-affected areas are increasing by the day. Although all grain legumes are sensitive to salinity stress, chickpea is one of the most susceptible ones. Salt stress reduces the osmotic potential in the medium and prevents water intake by seeds, moreover, increasing $\mathrm{Na}^{+}$and $\mathrm{Cl}^{-}$ions inhibited the germination process (Goharrizi et al., 2020). The first physiological process affected by salinity stress is water uptake due to the low water potential of the ambient. Salinity negatively affects plant growth throughout its lifespan, from germination to maturity, and causes significant stand establishment problems and yield losses (Singla and Garg, 2005). However, germination and early growth stage are the main critical stages for optimum stand establishment of plants (Hubbard et al., 2012).

Seed priming is controlled hydration of seeds soaked in a solution that has low osmotic potential to start the germination metabolism without elongation of radical (Sher et al., 2019). Many different methods are used as seed priming techniques such as hydro-priming, halopriming, solid matrix priming, osmo-priming, nutria-priming, hormonal priming and biopriming. Many researchers have reported that plant growth, tolerance to stress factors, stand establishment and productivity of crops can be improved by seed priming (Farooq et al., 2017; Reis et al., 2018; Haider et al., 2020; Maurya et al., 2020). Salicylic acid (SA) is commonly used as hormonal priming on different grain legumes such as lentil (Azarnia et al., 2016), faba bean (Bouallegue et al., 2017), common bean (Mohtashami et al., 2016), cowpea (Pakmehr et al., 2011), and pea (Farooq et al., 2007), therefore, reported to increase plant growth, seed yield, and tolerance to stress factors. The SA is a vital signaling molecule that regulates plant responses to pathogen infection (Shakirova et al., 2003). This study aims to evaluate whether SA priming is a technique that can be used to mitigate the toxic effects of salinity on the germination of chickpeas or not.

\section{MATERIAL AND METHOD}

\section{Material}

The seeds of cv. Çakır which is a kabuli type chickpea (Cicer arietinum L.) were provided from Transitional Zone Agricultural Research Institute. The selected cultivar has earliness (Anonymous, 2020) and salt-tolerant characteristics (Ceritoglu et al., 2020).

\section{Experimental Design and Treatment Details}

This study was laid out in the laboratory of Field Crops department, Siirt University, Turkey, during 2020. The experiment was conducted in a completely randomized design (CRD) with 3 replications. Three different $\mathrm{NaCl}$ doses (control, $50 \mathrm{mM}$ and $100 \mathrm{mM} \mathrm{NaCl}$ ) and 5 priming treatments (non-priming, hydro-priming, SA1: $0.1 \mathrm{mM}$, SA2: $0.2 \mathrm{mM}$ and SA3: $0.3 \mathrm{mM}$ salicylic acid) were used in the study. Before priming treatments, all tested seeds were surface-sterilized with $2.5 \%$ sodium hypochlorite for 5 minutes, thereafter, rinsed with distilled water 3 times (Gopalakrishnan et al., 2011). Hydro-primed seeds were soaked in distilled water for 18 hours where the seeds to solution ratio were 1:5 (w/v) (Farooq et al., 2017). The seeds were weighed and imbibed with salicylic acid (SA) solutions ( $3: 1$ seeds to solution ratio) for $12 \mathrm{~h}$ at $23^{\circ} \mathrm{C}$. The seeds were washed 3 times using distilled water to remove salicylic acid from the seed coat, followed by drying in blotter at laboratory temperature for 1 day until they had dried to original moisture content ( $\pm 3 \%$ ) (Jatana et al., 2020).

There was no evident split of seed coat or protrusion of radicle at the end of the priming period. Dry unprimed seeds were used as control. The experiment was carried out in Petri dishes $(90 \mathrm{~mm} \times 1.5 \mathrm{~mm})$ and 25 seeds were placed among two layers of moist filter papers. The filter papers in Petris were irrigated with $20 \mathrm{ml}$ solutions (distilled water, $50 \mathrm{mM} \mathrm{NaCl}$ and $100 \mathrm{mM} \mathrm{NaCl}$ ) at the beginning of the study. The filter papers were changed 
every 48 hours to prevent salt accumulation. The $20 \mathrm{ml}$ solution was given at every paper changing. The Petri dishes were placed in a closed system container in dark. The growth ambient temperature was maintained at 25 $\pm 2^{\circ} \mathrm{C}$ throughout the experiment stated by Ullah et al. (2019). The seeds were accepted to be germinated when the radicle length achieved $2 \mathrm{~mm}$ length (Matthews and Khajeh-Hosseini, 2007; Soleymani and Shahrajabian, 2018).

\section{Measurements and Observations}

The germination controls were done every 12 hours throughout the experiment duration and the study was finished on the $8^{\text {th }}$ day after sowing. At the end of 8 days, seeds were grouped as normal seedling, abnormal seedling, and dead seeds. Effects of different priming treatments under saline conditions on some germination traits such as germination percentage (GP), germination index (GI), mean germination time (MGT), germination rate (GR) and coefficient of uniformity of germination (CUG) were investigated in the study.

Germination percentage (GP): It was calculated on normal seedlings. The counting of germinated seeds was carried out at 12 hours intervals. According to Labouriau (1983), the germinability of a seed is the percentage of seeds where the germination process finishes by means of the intra-seminal growth results in the protrusion of one live embryo. This trait alone is an indicator of the viability of the population. The GP of tested seeds was determined with the following equation (Scott et al., 1984):

$$
G P=\frac{\text { Number of normal germinated seeds }}{\text { Number of total seeds }}
$$

Mean germination time (MGT): The MGT is a direct index of the time throughout germination process but does not highly correlate with uniformity and time spread. It especially focuses on the day when most seeds germinate. It was calculated using the following equation (Shoor et al., 2014):

$$
M G T=\frac{\sum N_{i} T_{i}}{\sum N_{i}}
$$

where $N_{i}$ is the number of normal germinated seeds at counting day, $T_{i}$ is the number of days from sowing day to counting day.

Germination rate (GR): The GR just expresses the germination percentage per day, therefore the higher GP and the shorter MGT provides the higher GR. It also provides information about the process in which the germination event intensifies within the total period of germination. Germination rate was estimated using the following equation (Ellis and Roberts, 1981):

$$
G R=\frac{\sum_{x}^{y} N}{\sum_{x}^{y} T}
$$

where $N$ is the number of normal germinated seeds, $T$ is days during the trial, $x$ is the first counting day and $y$ is the last counting day.

Germination index (Gl): Maximum importance is given to the seeds germinated on the first day while less to those germinated at later days. Thus, the GI focuses on both the GP and its speed. A higher Gl value points out a higher germinability and rate (Kader, 2015). The germination index was calculated using the following formula (Maguire, 1962):

$$
G I=\sum_{i}^{t} \frac{n_{i}}{t_{i}}
$$


where $n_{i}$ is the GP on the $\mathrm{i}^{\text {th }}$ day, $t_{i}$ is the number of counting days from start (i) to final day on which seeds germinated $(t)$. The higher germination rate represents more rapid germination for seeds.

Coefficient of uniformity of germination (CUG): The CUG states the variability of seeds concerning the MGT of the sample in the population (Ranal and De Santana, 2006). The CUG was estimated by using the following formula (Ellis and Roberts, 1981):

$$
C U G=\frac{\sum n}{\sum[(\bar{t}-t)]^{2} * n}
$$

where $n$ is the number of germinated seeds per counted day, $\bar{t}$ and $t$ are the MGT and the number of days from the start of germination to counting day, respectively.

\section{Statistical Analysis}

The values calculated were subjected to statistical analysis for the evaluation of significance within results. The normality of the data was tested using the Shapiro and Wilks (1965) normality test. One Way ANOVA and TUKEY Multivariate tests were calculated using JUMP software (JUMP Statistics for Windows, Version 5.0.1) for CRD replicated thrice.

\section{RESULTS AND DISCUSSION}

\section{Results}

According to results, $\mathrm{NaCl}$ doses, priming treatments and their interactions showed statistically significant $(<0.01$ ) differences (Table 1). The GP, MGT, GR, GI and CUG varied between 80.7-98.3\%, 1.40-2.67 day, 38.1-75.7, 37.5-72.5 and 0.3-0.7, respectively. It was determined that tested germination traits were negatively affected with increasing $\mathrm{NaCl}$ doses, therefore, most results were observed in control while the worst ones were obtained in the $100 \mathrm{mM}$ treatment. Although $50 \mathrm{~mL} \mathrm{NaCl}$ did not cause vital damage to germination traits, $100 \mathrm{mM}$ solutions significantly affected the seeds. Besides, hydro and salicylic acid treatments affected the germination process positively in general. The SA1 and SA2 priming caused improving all tested traits while SA3 inhibited the process. The highest values were observed with SA2 priming in all parameters.

Table 1. Analysis of variance on germination traits depending on salinity and priming treatments.

Çizelge 1. Tuzluluk ve priming uygulamalarına bağlı olarak çimlenme özelliklerine ilişkin varyans analizi.

\begin{tabular}{|c|c|c|c|c|c|c|c|c|c|c|c|}
\hline \multirow{2}{*}{$\begin{array}{l}\text { Source of } \\
\text { variation }\end{array}$} & \multirow[b]{2}{*}{ DF } & \multicolumn{2}{|c|}{ GP } & \multicolumn{2}{|c|}{ MGT } & \multicolumn{2}{|c|}{ GR } & \multicolumn{2}{|c|}{ GI } & \multicolumn{2}{|c|}{ CUG } \\
\hline & & MS & F prob. & MS & F prob. & MS & F prob. & MS & F prob. & MS & F prob. \\
\hline $\mathrm{NaCl}$ & 2 & 73.8 & ** & 1.98 & ** & 1161.7 & ** & 1691.3 & ** & 1511.0 & ** \\
\hline Priming & 4 & 160.2 & ** & 0.51 & ** & 587.5 & $\star \star$ & 611.2 & ** & 609.9 & ** \\
\hline $\mathrm{NaCl}$ x Priming & 8 & 7.5 & ** & 0.07 & ** & 34.3 & ** & 66.8 & ** & 40.4 & ** \\
\hline
\end{tabular}

(GP: Germination percentage, MGT: Mean germination time, GR: Germination rate, Gl: Germination index, CUG: Coefficient of uniformity of germination, MS: Means of the square, DF: Degree of freedom, ${ }^{*}:<0.01$ )

The $\mathrm{NaCl}$ doses and priming treatments significantly affected the GP (Table 1). While $50 \mathrm{mM} \mathrm{NaCl}$ treatment did not have a significant effect on GP, $100 \mathrm{mM} \mathrm{NaCl}$ caused a decrease of about $5 \%$ in the study. Hydro, SA1, and SA2 priming treatments increased the GP nearly $9.1 \%, 10.8 \%$, and $12.8 \%$, respectively. Although the SA3 priming increased the GP about $10.8 \%$ it exhibited a negative effect compared with the other SA treatments. The interaction between $\mathrm{NaCl}$ and priming treatments was statistically significant $(<0.01)$ in terms of GP. According to interaction, the highest GP was determined with SA2 priming in control while the lowest value was obtained with non-primed seeds in $100 \mathrm{mM} \mathrm{NaCl}$ solution. The decline in the GP achieved up to $10 \%$ in non-primed seeds whereas it just decreased by about 3.3\% in SA2 primed seeds (Table 2). 
Table 2. Effect of hydro and salicylic acid treatments on germination percentage (\%) of chickpea under salinity. Çizelge 2. Hidro ve salisilik asit uygulamalarının tuzluluk stresi altındaki nohutta çimlenme yüzdesine (\%) etkisi.

\begin{tabular}{lcccccc}
\hline Salinity levels & $\begin{array}{c}\text { Non- } \\
\text { primed }\end{array}$ & $\begin{array}{c}\text { Hydro- } \\
\text { priming }\end{array}$ & SA1 & SA2 & SA3 & Mean \\
\hline Control & $90.0 \mathrm{ef}$ & $95.0 \mathrm{ac}$ & $95.7 \mathrm{ab}$ & $98.3 \mathrm{a}$ & $95.0 \mathrm{abc}$ & $94.8 \mathrm{a}$ \\
$\mathbf{5 0} \mathbf{~} \mathbf{M ~ N a C l}$ & $87.3 \mathrm{f}$ & $94.7 \mathrm{a}-\mathrm{d}$ & $95.7 \mathrm{ab}$ & $97.7 \mathrm{ab}$ & $94.3 \mathrm{bcd}$ & $93.9 \mathrm{a}$ \\
$\mathbf{1 0 0} \mathbf{~ m M ~ N a C l}$ & $80.7 \mathrm{~g}$ & $91.7 \mathrm{cde}$ & $94.7 \mathrm{a}-\mathrm{d}$ & $95.0 \mathrm{abc}$ & $91.0 \mathrm{def}$ & $90.6 \mathrm{~b}$ \\
\hline Mean & $86.0 \mathrm{~d}$ & $93.8 \mathrm{bc}$ & $95.3 \mathrm{ab}$ & $97.0 \mathrm{a}$ & $93.4 \mathrm{c}$ & \\
TUKEY & $11.06^{\star *}$ & & & & & \\
TUKEY & $1.76^{\star *}$ & & & & & \\
TUKEY & $3.88^{\star *}$ & & & & & \\
\hline
\end{tabular}

(Hydro-priming: primed with distilled water, SA1: $0.1 \mathrm{mM}$ salicylic acid, SA1: $0.1 \mathrm{mM}$ salicylic acid, SA1: $0.1 \mathrm{mM}$ salicylic acid)

Both treatments and their interaction had statistically significant differences (Table1). According to results, the MGT varied between 1.61-2.33 days depending on $\mathrm{NaCl}$ doses while it changed between 1.59-2.17 days with priming treatments. The longest MGT (2.67 days) was determined with non-primed seeds in $100 \mathrm{mM} \mathrm{NaCl}$ solution while the earliest one (1.4 days) was observed with SA2 in the control treatment. Even though all treatments positively affected the MGT, $0.3 \mathrm{mM}$ SA caused inhibition and delay (Table 3).

Table 3. Effect of hydro and salicylic acid treatments on mean germination time (day) of chickpea under salinity Çizelge 3. Hidro ve salisilik asit uygulamalarının tuzluluk stresi altındaki nohutta ortalama çimlenme süresine (gün) etkisi

\begin{tabular}{|c|c|c|c|c|c|c|}
\hline Salinity levels & $\begin{array}{l}\text { Non- } \\
\text { primed }\end{array}$ & $\begin{array}{l}\text { Hydro- } \\
\text { priming }\end{array}$ & SA1 & SA2 & SA3 & Mean \\
\hline Control & $1.77 \mathrm{~h}$ & $1.65 \mathrm{i}$ & $1.54 \mathrm{j}$ & $1.40 \mathrm{k}$ & $1.67 \mathrm{i}$ & $1.61 \mathrm{c}$ \\
\hline $50 \mathrm{mM} \mathrm{NaCl}$ & $2.07 \mathrm{e}$ & $2.04 \mathrm{e}$ & $1.88 \mathrm{~g}$ & $1.42 \mathrm{k}$ & $2.39 \mathrm{bc}$ & $1.96 \mathrm{~b}$ \\
\hline $100 \mathrm{mM} \mathrm{NaCl}$ & $2.67 \mathrm{a}$ & $2.44 \mathrm{~b}$ & $2.33 \mathrm{~d}$ & $1.95 \mathrm{f}$ & $2.37 \mathrm{c}$ & $2.33 a$ \\
\hline Mean & $2.17 \mathrm{a}$ & $2.04 \mathrm{C}$ & $1.88 \mathrm{~d}$ & $1.59 \mathrm{e}$ & $2.14 \mathrm{~b}$ & \\
\hline TUKEY $_{(\mathrm{NaCl})}$ & $0.018^{* *}$ & & & & & \\
\hline TUKEY (Priming) & $0.028^{* *}$ & & & & & \\
\hline TUKEY (NaClxPriming) & $0.061^{* *}$ & & & & & \\
\hline
\end{tabular}

(Hydro-priming: primed with distilled water, SA1: $0.1 \mathrm{mM}$ salicylic acid, SA1: $0.1 \mathrm{mM}$ salicylic acid, SA1: $0.1 \mathrm{mM}$ salicylic acid)

Germination index was significantly $(<0.01)$ affected by $\mathrm{NaCl}$ doses, priming treatments, and their interaction (Table 1). The increasing $\mathrm{NaCl}$ caused a decrease in the Gl. Also, all priming treatments improved the $\mathrm{Gl}$ except SA3 priming. The highest GI was obtained with SA2 in control while the lowest one was obtained from SA3 in 100 $\mathrm{mM} \mathrm{NaCl}$ solution (Table 4).

Table 4. Effect of hydro and salicylic acid treatments on germination index of chickpea under salinity. Çizelge 4. Hidro ve salisilik asit uygulamalarının tuzluluk stresi altındaki nohutta çimlenme indeksine etkisi.

\begin{tabular}{lcccccc}
\hline Salinity levels & $\begin{array}{c}\text { Non- } \\
\text { primed }\end{array}$ & $\begin{array}{c}\text { Hydro- } \\
\text { priming }\end{array}$ & SA1 & SA2 & SA3 & Mean \\
\hline Control & $68.0 \mathrm{c}$ & $68.7 \mathrm{c}$ & $65.3 \mathrm{~d}$ & $75.7 \mathrm{a}$ & $61.6 \mathrm{e}$ & $67.9 \mathrm{a}$ \\
$\mathbf{5 0 ~} \mathbf{~ m ~ N a C l}$ & $47.1 \mathrm{~h}$ & $53.0 \mathrm{~g}$ & $63.2 \mathrm{de}$ & $73.2 \mathrm{~b}$ & $41.9 \mathrm{i}$ & $55.7 \mathrm{~b}$ \\
$\mathbf{1 0 0} \mathbf{~ m M ~ N a C l}$ & $40.6 \mathrm{i}$ & $46.0 \mathrm{~h}$ & $51.0 \mathrm{~g}$ & $57.7 \mathrm{f}$ & $38.1 \mathrm{j}$ & $46.7 \mathrm{c}$ \\
\hline Mean & $51.9 \mathrm{~d}$ & $55.9 \mathrm{c}$ & $59.9 \mathrm{~b}$ & $68.9 \mathrm{a}$ & $47.2 \mathrm{e}$ & \\
TUKEY & & & & & & \\
TUKEY & & & & & & \\
TUKEY & $1.69^{* *}$ & & & & & \\
\hline
\end{tabular}

(Hydro-priming: primed with distilled water, SA1: $0.1 \mathrm{mM}$ salicylic acid, SA1: $0.1 \mathrm{mM}$ salicylic acid, SA1: 0.1 mM salicylic acid)

All treatments and interactions among them showed a statistically significant difference $(p<0.01)$ on the GR (Table 1). The GR changed between 45.1-62.7 and 47.5-67.1depending on $\mathrm{NaCl}$ doses and priming treatments, respectively. The highest value was obtained from SA2 priming in the control treatment whereas the lowest one was determined with non-primed seeds in $100 \mathrm{mM} \mathrm{NaCl}$ solution. The GR was noteworthily affected by increasing salinity levels. Also, while hydro, SA1 and SA2 priming positively affected the GR, SA3 priming caused inhibition (Table 5). 
Table 5. Effect of hydro and salicylic acid treatments on germination rate of chickpea under salinity. Çizelge 5. Hidro ve salisilik asit uygulamalarının tuzluluk stresi altındaki nohutta çimlenme hızına etkisi.

\begin{tabular}{|c|c|c|c|c|c|c|}
\hline Salinity levels & $\begin{array}{l}\text { Non- } \\
\text { primed }\end{array}$ & $\begin{array}{l}\text { Hydro- } \\
\text { priming }\end{array}$ & SA1 & SA2 & SA3 & Mean \\
\hline Control & $56.6 \mathrm{~cd}$ & $60.4 \mathrm{bc}$ & $63.6 \mathrm{~b}$ & $72.5 \mathrm{a}$ & $60.2 \mathrm{bc}$ & $62.7 \mathrm{a}$ \\
\hline 50 mM NaCl & $48.5 \mathrm{fg}$ & 50.8 ef & $53.6 \mathrm{de}$ & $70.2 \mathrm{a}$ & $41.1 \mathrm{hi}$ & $52.9 \mathrm{~b}$ \\
\hline 100 mM NaCl & $37.5 i$ & $41.0 \mathrm{hi}$ & $46.3 \mathrm{~g}$ & $58.5 \mathrm{c}$ & $42.2 \mathrm{~h}$ & $45.1 \mathrm{c}$ \\
\hline Mean & $47.5 \mathrm{~d}$ & $50.8 \mathrm{c}$ & $54.5 \mathrm{~b}$ & $67.1 \mathrm{a}$ & $47.8 \mathrm{~d}$ & \\
\hline TUKEY $_{(\mathrm{NaCl})}$ & $1.17^{\star *}$ & & & & & \\
\hline TUKEY (Priming) & $1.77^{\star *}$ & & & & & \\
\hline TUKEY (NaClxPriming) & $3.90^{* *}$ & & & & & \\
\hline
\end{tabular}

(Hydro-priming: primed with distilled water, SA1: $0.1 \mathrm{mM}$ salicylic acid, SA1: $0.1 \mathrm{mM}$ salicylic acid, SA1: $0.1 \mathrm{mM}$ salicylic acid)

The coefficient of uniformity of germination significantly changed depending on salinity levels, seed priming treatments, and their interaction in the study (Table 1). The CUG was negatively affected by increasing salinity levels. Although all priming treatments positively affected the CUG, $0.3 \mathrm{mM} \mathrm{SA}$ exhibited a detrimental impact compared to the other applications. The highest CUG value was recorded with SA2 (0.7) in control while the lowest one (0.30) was obtained from non-primed seeds in $100 \mathrm{mM} \mathrm{NaCl}$ solution (Table 6).

Table 6. Effect of hydro and salicylic acid priming on the coefficient of uniformity of germination in chickpea under salinity. Çizelge 6. Hidro ve salisilik asit uygulamalarının tuzluluk stresi altındaki nohutta çimlenme üniformluk katsayısına etkisi.

\begin{tabular}{|c|c|c|c|c|c|c|}
\hline Salinity levels & $\begin{array}{l}\text { Non- } \\
\text { primed }\end{array}$ & $\begin{array}{l}\text { Hydro- } \\
\text { priming }\end{array}$ & SA1 & SA2 & SA3 & Mean \\
\hline Control & $0.50 \mathrm{~d}$ & $0.58 \mathrm{c}$ & $0.62 \mathrm{~b}$ & $0.70 \mathrm{a}$ & $0.57 c$ & $0.60 \mathrm{a}$ \\
\hline 50 mM NaCl & $0.42 \mathrm{fg}$ & $0.46 \mathrm{e}$ & $0.51 \mathrm{~d}$ & $0.69 a$ & $0.40 \mathrm{gh}$ & $0.50 \mathrm{~b}$ \\
\hline $100 \mathrm{mM} \mathrm{NaCl}$ & $0.30 \mathrm{i}$ & $0.38 \mathrm{~h}$ & $0.42 \mathrm{f}$ & $0.49 \mathrm{de}$ & $0.38 \mathrm{~h}$ & $0.40 \mathrm{c}$ \\
\hline Mean & $0.41 \mathrm{e}$ & $0.47 c$ & $0.52 \mathrm{~b}$ & $0.63 \mathrm{a}$ & $0.45 \mathrm{~d}$ & \\
\hline TUKEY $_{(\mathrm{NaCl})}$ & $0,007^{* *}$ & & & & & \\
\hline TUKEY (Priming) & $0.011^{\star *}$ & & & & & \\
\hline TUKEY (NaClxPriming) & $0.028^{* *}$ & & & & & \\
\hline
\end{tabular}

(Hydro-priming: primed with distilled water, SA1: $0.1 \mathrm{mM}$ salicylic acid, SA1: 0.1 mM salicylic acid, SA1: 0.1 mM salicylic acid)

\section{DISCUSSION}

High salt concentrations in soil or growth medium negatively affect the germination process in all but a few species (Zapata et al., 2004). Increasing salinity in growth media causes inhibition of the germination process by creating osmotic potential that prevents water uptake by the seed (Grewal, 2010) and by the toxicity of $\mathrm{Na}^{+}$and $\mathrm{Cl}^{-}$ions (Chen et al., 2020). The present study demonstrated that increasing salinity levels negatively affect germination, and also, $\mathrm{NaCl}$ doses higher than $50 \mathrm{mM}$ caused vital damages to the germination and growth stages of plants (Kim et al., 2012; Thomas et al., 2013; Ceritoglu et al., 2020). In contrast to increasing salinity levels, seed priming treatments (hydro and SA) improved germination properties in control treatments and enable mitigation of the toxic effects of salinity on the germination of seeds in $\mathrm{NaCl}$ solutions. The germination traits of primed seeds exhibited higher performance than non-primed ones under salinity and control conditions. Because SA priming leads to remain metabolic energy due to an increase in energy charge (EC), adenosine triphosphate (ATP), and ATP/ADP ratio (Varier et al., 2010).

The GP is the mean indicator of a population and a higher GP value shows greater germination. Salinity inhibits the GP due to osmotic and/or specific ion toxicity that may restrict water uptake (Aflaki et al., 2017). Although 50 $\mathrm{mM} \mathrm{NaCl}$ did not affect the GP, $100 \mathrm{mM}$ solution noteworthy reduced it in the study. So, it can be concluded that $100 \mathrm{mM}$ or higher concentration of $\mathrm{NaCl}$ is a critical threshold on chickpea germination in the present study. Different researchers reported that chickpea is a salt-sensitive species and is negatively affected by increasing salinity levels during germination and early seedling stages (Özaktan et al., 2018; Lavrenko et al., 2019). The SA, due to its characteristics, is considered as a signal molecule that affects some physiological processes of germination (Asadi et al., 2013). Therefore, SA1 and SA2 not only exhibited positive effects on GP, and also improved other germination processes including; the speed of germination, elongation of the radicle, and uniformity of emergence. According to Janda et al. (2007), the interaction between salinity and SA might be caused by induced genes encoding of resistance that seems to act on germination with increasing physiological 
activity. However, higher doses of SA showed a detrimental effect on germination because it causes a decrease in chlorophyll content in some plants (Asadi et al., 2013).

Although the MGT is a precise measure of the germination time of tested seeds, it is not related to spreading on time and germination uniformity. The MGT focuses on the day when most germination events constituted. The MGT was changed by increasing $\mathrm{NaCl}$ levels and priming treatments. Reduction in the MGT with increasing salinity is thought to be caused that $\mathrm{NaCl}$ creates an osmotic barrier inhibiting the water uptake. This result is in agreement with the findings of Kaya et al. (2008). Hydro-priming and SA-priming led to mitigation of salinity harmful effects on the MGT. Sakhabutdinova et al. (2003) demonstrated that SA treatments promote the cytokinin and indoleacetic acid in the tissues of plant, therefore, the cell division is enhanced.

The GI is the most exhaustive parameter related to germination combining GP and speed. Thus, it allows an easy comparison of the germination properties of tested seeds. Higher GI value symbolized that seeds have a good germination quality and are a preview of uniformity emergence. While the Gl was slightly decreased at 50 $\mathrm{mM} \mathrm{NaCl}$, it was sharply inhibited at $100 \mathrm{mM} \mathrm{NaCl}$ compared with control. The mean reason for this sharp decrease is thought to cause excessive $\mathrm{Na}^{+}$accumulation that may cause osmotic and metabolic problems. Also, $\mathrm{Na}^{+}$toxicity might result in dormancy and delay emergence. It was largely seemed due to its high ability to compete for $\mathrm{K}^{+}$for binding sites (Yildirim et al., 2009). $\mathrm{K}^{+}$plays a significant role in osmoregulation, stomatal behavior, cell expansion, enzyme activity, membrane polarization, and neutralization of negative ions (Qin et al., 2010). Moreover, $\mathrm{Na}^{+}$and $\mathrm{Cl}^{-}$ions can enter into the cells and cause toxic effects on both cell membranes and metabolic activities in the cytosol (Cha-Um and Kirdmanee, 2010; Zhu et al., 2019).

The GR focuses on the time required for reaching germination. The GR reflects the percentage of germination on each day of the germination period. The main factors affecting the GR are water uptake and temperature. Also, all factors affecting water uptake such as seed size (Zhang et al., 2010) and osmotic potential of cells or medium (Piovan et al., 2019) determine the speed of germination. So, high ion concentration at seed coat and its toxic impact on enzymatic process inhibited the germination and led to delay elongation of radicle. Besides, the detrimental effect of salinity is partly alleviated by seed priming. The SA might mitigate the imposed salinity due to osmotic regulation or by providing resistance to plant cells. However, some points are not clear about the role of SA on the biochemical compounds yet (Boukraa et al., 2013).

The CUG refers to fluctuations or stability of germination times between the first and last germinated seeds. Thus, higher values of CUG represent the stability of seeds in the population while lower values denote large variability in the same conditions (Souhail and Chaabane, 2009). The uniformity of germination has a vital role in the homogeneity of germination for crop plants. Non-homogenous emergence negatively affects plant growth, grain yield and seed quality due to irregularity in phenological duration. Salinity causes changing the rate of water uptake affecting osmotic potential (Sher et al., 2019). Thus, some seeds can germinate slower, and also the others may never germinate. This situation caused to reduce the uniformity of germination. Even with a small amount of water intake, the seeds may reach the germination potential. Due to the support of both enzymatic and metabolic activities and the decrease of water potential needed for seeds, they provide a uniform emergence in a short time under optimum conditions. The SA applied at a higher dose is thought to negatively affect the germination process by disrupting hormonal balance. Therefore, salicylic acid priming might be used as an efficient solution for the mitigation of salinity stress on the germination process in chickpea.

\section{CONCLUSION}

Salinity is a major problem sharply affecting the chickpea growth from germination to maturity. All of the germination processes were negatively affected by increasing $\mathrm{NaCl}$ concentration. Germination rate, germination index and uniformity of germination are vital parameters especially for field crop seeds to compete with weed seeds. In addition, uniformity of germination is a substantial point in terms of homogenous physiological growth periods. The seed priming, which is an easily applicable and cheap technique, has significant potential for the mitigation of soil salinity on seed germination. Also, there is a need for further studies to exactly understand the effects of different priming techniques on vegetative growth and yield parameters under salinity stress.

\section{CONFLICT OF INTEREST}

There are no conflicts of interest between authors. 


\section{DECLARATION OF AUTHOR CONTRIBUTION}

Mustafa CERITOGLU conceived and designed the research, collected the data, and contributed to the writing of the paper. Murat ERMAN contributed to analyze of data and write of the paper.

\section{ACKNOWLEDGMENT}

The authors thank Dr. Figen CERITOGLU and Dr. Harun BEKTAS for contributions to the analysis of data and discussion of results.

\section{REFERENCES}

Aflaki, F., Sedghi, M., Pazuki, A., \& Pessarakli, M. (2017). Investigation of seed germination indices for early selection of salinity tolerant genotypes: A case study in wheat. Emirates Journal of Food and Agriculture, 29(3), 222-226.

Anonymous. (2020). Registry properties of Çakır chickpea cultivar. Available at: https://arastirma.tarimorman.gov.tr/gktaem/Belgeler/Tescilli\%20\%C3\%87e\%C5\%9Fitlerimiz/Nohut/cakir.pdf. Access date: June 10, 2020.

Asadi, M., Heidari, M. A., Kazemi, M., \& Filinejad, A. R. (2013). Salicylic acid induced changes in some physiological parameters in chickpea (Cicer arietinum L.) under salt stress. Journal of Agricultural Technology, 9(2), 311-316.

Azarnia, M., Biabani, A., Eisvand, H. R., Alamdari, E. G., \& Safikhani, S. (2016). Effect of seed priming with gibberellic acid and salicylic acid on germination characteristic and seed and seedlings physiological quality of lentil (Lens culinaris L.). Iranian Journal of Seed Research, 3(1), 59-72.

Bouallegue, A., Soissi, F., Nouairi, I., Souibgui, M., Abbes, Z., \& Mhadhbi, H. (2017). Salicylic acid and hydrogen peroxide pretreatments alleviate salt stress in faba bean (Vicia faba) seeds during germination. Seed Science and Technology, 45(3), 675-690.

Boukraa, D., Benabdelli, K., Belabid, L., \& Bennabi, F. (2013). Effect of salinity on chickpea seed germination pre-treated with salicylic acid. Scientific Journal of Biological Sciences, 2(4), 86-93.

Cha-Um, S., \& Kirdmanee, C. (2010). Effect of glycine betaine on proline, water use, and photosynthetic efficiencies, and growth of rice seedlings under salt stress. Turkish Journal of Agriculture and Forestry, 34, 517-527.

Chen, T., Pineda, I. M. G., Brand, A. M., \& Stützel, H. (2020). Determining ion toxicity in cucumber under salinity stress. Agronomy, 10(5), 667.

Ceritoglu, M., \& Erman, M. (2019). Tane baklagillerin ekim nöbetinde kullanılması. VI. International Conference on Mathematic - Engineering- Natural \& Medical Science, Adana.

Ceritoglu, M., Erman, M., \& Yildiz, F. (2020). Effect of salinity on germination and some agro-morfological traits in chickpea seedling. ISPEC Journal of Agricultural Science, 4(1), 82-96.

Ellis, R. A., \& Roberts, E. H. (1981). The quantification of ageing and survival in orthodox seeds. Seed Science and Technology, 9, 373-409.

FAOSTAT. (2018). Chickpea production. Online database at https://www.fao.org/faostat/ en/\#data. Access date: June 5, 2020.

Farooq, M., Basra, S. M. A., Tauseef, M., Rehman, H., \& Munir, H. (2007). Priming with ethanol, ascorbate and salicylicate enhances the germination and early seedling growth of pea (Pisum sativum L.). Pakistan Journal of Agricutural Science, 44(1), 30-39.

Farooq, M., Hussain, M., Nawaz, A., Lee, D., Alghamdi, S. S., \& Siddique, K. H. M. (2017). Seed priming improves chilling tolerance in chickpea by modulating germination metabolism, trehalose accumulation and carbon assimilation. Plant Physiology and Biochemistry, 111, 274-283.

Francis, C., Jones, A., Crookston, K., Wittler, K., \& Goodman, S. (1986). Strip cropping corn and grain legumes: A review. American Journal of Alternative Agriculture, 1(4), 159-164.

Gan, Y., Zentner, R. P., McDonald, C. L., Warkentin, T., \& Vandenberg, A. (2009). Adaptability of chickpea in northern high latitude areas-Maturity responses. Agricultural and Forest Meteorology, 149(3-4), 711-720.

Gopalakrishnan, S., Pande, S., Sharma, M., Humayun, P., Kiran, B. K., Sandeep, D., Vidya, M. S., Deepthi, K., \& Rupela, O. (2011). Evaluation of actinomycete isolates obtained from herbal vermicompost for the biological control of Fusarium wilt of chickpea. Crop Protection, 30(8), 1070-1078. 
Goharrizi, K. J., Amirmahani, F., \& Salehi, F. (2020). Assessment of changes in physiological and biochemical traits in four pistachio rootstocks under drought, salinity and drought + salinity stresses. Physiologia Plantarum, 168, 973-989.

Grewal, H. S. (2010). Water uptake, water use efficiency, plant growth and ionic balance of wheat, barley, canola and chickpea plants on a sodic vertosol with variable subsoil NaCl salinity. Agricultural Waste Management, 97(1), 148-156.

Haider, M. U., Hussain, M., Farooq, M., \& Nawaz, A. (2020). Optimizing zinc seed priming for improving the growth, yield and grain biofortification of mungbean (Vigna radiata (L.) wilczek). Journal of Plant Nutrition, 43(10), 1438-1446.

Hajjarpoor, A., Vadez, V., Soltani, A., Gaur, P., Whitbread, A., Babu, D. S., Gumma, M. K., Diancoumba, M., \& Kholova, J. (2018). Characterization of the main chickpea cropping systems in India using a yield gap analysis approach. Field Crops Research, 223, 93-104.

Hubbard, M., Germida, J., \& Vujanovic, V. (2012). Fungal endophytes improve wheat seed germination under heat and drought stress. Botany, 90, 137-149.

Janda, T., Horváth, E., Szalai, G., \& PáLdi, E. (2007). Role of Salicylic Acid in the Induction of Abiotic Stress Tolerance. In: Hayat S., Ahmad A. (eds) Salicylic Acid: A Plant Hormone. Dordrecht: Springer. https://doi.org/10.1007/1-4020-5184-0_5

Jatana, B. S., Ram, H., \& Gupta, N. (2020). Application of seed and foliar priming strategies to improve the growth and productivity of late sown wheat (Triticum aestivum L.). Cereal Research Communications.

Kader, M. A. (2015). A comparison of seed germination calculation formulae and the associated interpretation of resulting data. Journal and Proceedings of the Royal Society of New South Wales, 138, 65-75.

Kaya, M., Kaya, G., Kaya, M. D., Atak, M., Sağlam, S., Khawar, K. M., \& Çiftçi, C. Y. (2008). Interaction between seed size and NaCl on germination and early seedling growth of some Turkish cultivars of chickpea (Cicer arietinum L.). Journal of Zhejiang University Science B, 9(5), 371-377.

Kim, S., Rayburn, A. L., Voigt, T., Parrish, A., \& Lee, D. K. (2012). Salinity effects on germination and plant growth of prairie cordgrass and switchgrass. BioEnergy Research, 5, 225-235.

Labouriau, L. G. (1983). A germinação das sementes. Organização dos Estados Americanos. Programa Regional de Desenvolvimento Científico e Tecnológico. Série de Biologia. Monografia.

Lavrenko, S. O., Lavrenko, N. M., \& Lykhovyd, P. V. (2019). Effect of degree of salinity on seed germination and initial growth of chickpea (Cicer arietinum). Biosystem Diversity, 27(2), 101-105.

Maguire, J. D. (1962). Speed of germination-aid in selection and evaluation for seedling emergence and vigor. Crop Science, $2,176-177$.

Matthews, S., \& Khajeh-Hosseini, M. (2007). Length of the lag period of germination and metabolic repair explain vigour differences in seed lots of maize (Zea mays). Seed Science and Technology, 35(1), 200-213.

Maurya, D. K., Hasanain, M., Verma, S. K., Singh, P. K., Kumar, V., Singh, S., \& Mishra, R. (2020). Seed priming and its effect on enhancing pulse productivity. Food and Scientific Reports, 1, 20-22.

Mohtashami, M., Naderi, A., Ghanbari, A. A., Alavifazel, M., \& Lak, S. (2016). Effect of seed pre-treatment with growth regulators on seed yield and yield components of common bean (Phaseolus vulgaris L.). Turkish Journal of Field Crops, 21(2), 313-317.

Özaktan, H., Çiftçi, C. Y., Kaya, M. D., Uzun, S., Uzun, O., \& Akdogan, G. (2018). Chloride salts inhibit emergence and seedling growth of chickpea rather than germination. Legume Research, 41(1), 60-66.

Pakmehir, A., Rastgoo, M., Shekari, F., Saba, J., Vazayefi, M., \& Zangani, A. (2011). Effect of salicylic acid priming on yield and yield components of cowpea (Vigna unguiculata L.) under water deficit at reproductive stage. Iranian Journal of Pulse Research, 2(1), 53-64.

Piovan, M. J., Pratolongo, P., Donath, T. W., Loydi, A., \& Eckstein, L. (2019). Germination response to osmotic potential, osmotic agents, and temperature of five halophytes occurring along a salinity gradient. International Journal of Plant Science, 180(4), 345-355.

Ranal, M. A., \& De Santana, D. G. (2006). How and why to measure the germination process?. Revista Brasileira de Botanica, 29(1), 1-11.

Reis, S., Pavia, I., Carvalho, A., Moutinho-Perreira, J., Correira, C., \& Brito, J. L. (2018). Seed priming with iron and zinc in bread wheat: effects in germination, mitosis and grain yield. Protoplasma, 255, 1179-1194.

Qin, J., Dong, W. Y., He, K. N., Yu, Y., Tan, G. D., Han, L., Dong, M., Zhang, Y. Y., Zhang, D., Li, A. Z., \& Wang, Z. L. (2010). NaCl salinity-induced changes in water status, ion contents and photosynthetic properties of Shepherdia argentea (Pursh) Nutt seedlings. Plant, Soil and Environment, 56, 325-332. 
Roorkiwal, M., Jain, A., Kale, S. M., Doddamani, D., Chitikineni, A., Thudi, M., \& Varshney, R. K. (2018). Development and evaluation of high-density Axiom ${ }^{\circledR}$ CicerSNP Array for high-resolution genetic mapping and breeding applications in chickpea. Plant Biotechnology Journal, 16, 890-901.

Sakhabutdinova, A. R., Fatkhutdinova, D. R., Bezrukova, M. V., \& Shakirova., F. M. (2003). Salicylic acid prevents damaging action of stress factors on wheat plants. Bulgarian Journal of Plant Physiology, Special Issue, 314-319.

Scott, S. J., Jones, R. A., \& Williams, W. A. (1984). Review of data analysis methods for seed germination. Crop Science, 24, 11921199.

Shahid, S. A., Zaman, M., \& Heng, L. (2018). Soil Salinity: Historical perspectives and a world overview of the problem. In: Guideline for Salinity Assessment, Mitigation and Adaptation Using Nuclear and Related Techniques. Cham: Springer.

Shakirova, F. M., Sakhabutdinova, A. R., Bezrukova, M. V., Fatkhutdinova, R. A., \& Fatkhutdinova, D. R. (2003). Changes in the hormonal status of wheat seedlings induced by salicylic acid and salinity. Plant Science, 164(3), 317-322.

Shapiro, S. S., \& Wilk, M. B. (1965). An analysis of variance test for normality (complete samples). Biometrika, 52(34), 591-611.

Sher, A., Sarwar, T., Nawaz, A., ljaz, M., Sattar, A., \& Ahmad, S. (2019). Methods of seed priming. Priming and Pretreatment of seeds and seedling, Singapore: Springer.

Shoor, M., Afrousheh, M., Rabeie, J., \& Vahidi, M. (2014). The effect of salinity priming on germination and growth stage of cumin (Cuminum cyminum L.). Research Journal of Agricultural and Environmental Management, 3(7), 340-352.

Singla, R., \& Garg, N. (2005). Influence of salinity on growth and yield attributes in chickpea cultivars. Turkish Journal of Agriculture and Forestry, 29, 231-235.

Soe, K. M., Htwe, A. Z., Moe, K., Tomomi, A., \& Yamakawa, T. (2020). Diversity and effectivity of indigenous Mesorhizobium strains for chickpea (Cicer arietinum L.) in Myanmar. Agronomy, 10(2), 287.

Soleymani, A., \& Shahrajabian, M. H. (2018). Changes in germination and seedling growth of different cultivars of cumin to drought stress. Cercetări Agronomice în Moldova, 1(173), 91-100.

Souhail, M., \& Chaabane, R. (2009). Toxicity of the salt and pericarp inhibition on the germination of some Atriplex species. American-Eurasian Journal of Toxicological Sciences, 1(2), 43-49.

Soysal, S., Uçar, Ö., \& Erman, M. (2020). The effects of different plant densities on yield and some yield characteristics of chickpea (Cicer arietinum L.) on the ecological conditions of Siirt province. EJONS International Journal on Mathematics, Engineering and Natural Sciences, 4(15), 785-795.

Thomas, S., Anand, A., Chinnusamy, V., Dahaju, A., \& Basu, S. (2013)._Magnetopriming circumvents the effect of salinity stress on germination in chickpea seeds. Acta Physiologiae Plantarum, 35, 3401-3411.

Ullah, A., Farooq, M., Hussain, M., Ahmad, R., \& Wakeel, A. (2019). Zinc seed priming improves stand establishment, tissue zinc concentration and early seedling growth of chickpea. The Journal of Animal and Plant Science, 29(4), 1046-1053.

Xing, Q., Dekker, S., Kyriakopoulou, K., Boom, R. M., Smid, E. J., \& Schutyser, M. A. I. (2020). Enhanced nutritional value of chickpea protein concentrate by dry separation and solid state fermentation. Innovative Food Science and Emerging Technologies, 59, 102269.

Varier, A., Vari, A. K., \& Dadlani, M. (2010). The subcellular basis of seed priming. Current Science, 99, 450-456.

Varshney, R. K, Thudi, M., Nayak, S. N., Gaur, P. M., Kashiwagi, J., Krishnamurthy, L., Jaganathan, D., Koppolu, J., Bohra, A., Tripathi, S., Rathore, A., Jukanti, A. K., Jayalakshmi, V., Vemula, A., Singh, S. J., Yasin, M., Sheshshayee, M. S., \& Viswanatha, K. P. (2014) Genetic dissection of drought tolerance in chickpea (Cicer arietinum L.). Theoretical and Applied Genetics, 127, 445-462.

Yildirim, E., Karlidag, H., \& Turan, M. (2009). Mitigation of salt stress in strawberry by foliar K, Ca and Mg nutrient supply. Plant, Soil and Environment, 55, 213-221.

Zapata, P. J., Serrano, M., Pretel, M. T., Amoros, A., \& Botella, M. A. (2004). Polyamines and ethylene changes during germination of different plant species under salinity. Plant Science, 167(4), 781-788.

Zhang, H., Irving, L. J., McGill, C., Matthew, C., Zhou, D., \& Kemp, P. (2010.) The effects of salinity and osmotic stress on barley germination rate: sodium as an osmotic regulator. Annals of Botany, 106, 1027-1035.

Zhu, G., An, L., Jiao, X., Chen, X., Zhou, G., \& McLaughlin, N. (2019). Effects of gibberellic acid on water uptake and germination of sweet sorghum seeds under salinity stress. Chilean Journal of Agricultural Research, 79(3), 415-424. 